\title{
Deep processes, velocity, heat and density models of the East Kamchatka upper mantle
}

\author{
V.V. Gordienko1 ${ }^{\prime}$,L.I. Gontovaya ${ }^{2}$, I. V. Nizkous ${ }^{3}, 2020$ \\ ${ }^{1}$ Subbotin Institute of Geophysics, National Academy of Sciences, Kiev, Ukraine \\ ${ }^{2}$ Institute of Volcanology and Seismology, Far Eastern Branch of the Russian Academy \\ of Sciences, Petropavlovsk-Kamchatsky, Russia \\ ${ }^{3}$ Innovation Technology Group ESG Solutions, Kingston, Ontario, Canada
}

Received 8 July 2019

\begin{abstract}
Аля швидкісної структури літосфери Східної Камчатки побудовано томографічну модель високого просторового розрізнення. Модель демонструє чіткий зв'язок значень сейсмічної швидкості в мантії і в підповерхневій структурі. Зміна швидкості поширення $P$-хвиль відносно середньої 1D моделі сягає $\pm 0,6$ км/с. Помітне положення астеносфери або інтервалу глибин із швидкостями, нижчими, ніж на рівні солідуса. Сейсмологічна модель може бути використана для контролю моделі глибинних процесів у досліджуваному регіоні. Розглянуто схему альпійських і сучасних глибинних процесів у корі та верхній мантії Східної Камчатки і Кроноцького залива 3 використанням уявлень адвекційно-поліморфної гіпотези. Наслідки цих процесів узгоджуються з швидкісною моделлю мантії та складом магматичних порід. Використано дані стосовно ксенолітів із земної кори і складу магматичних порід різного віку та різної глибини розміщення осередків часткового плавлення мантійних порід. Глибина залягання провідників у верхній мантії відповідає глибині розміщення асте-

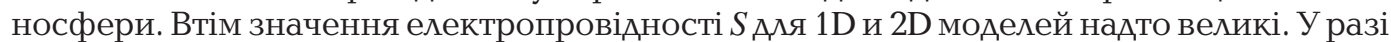
використання тривимірної моделі у південній частині Камчатки величина $S$ об'єктів електропровідності в мантії зменшується. Таким чином, узгодження з тепловою моделлю уявляється можливим. Розглянуто результати побудови щільнісних моделей тектоносфери уздовж трьох профілів на Східній Камчатці і суміжній акваторії. Аля моделі верхньої мантії використано теплову модель, що відповідає схемі глибинного процесу за адвекційно-поліморфною гіпотезою. Мантійна гравітаційна аномалія сягає значної величини - понад 200 мГал. Показано можливість пояснення спостереженого гравітаційного поля без підбору параметрів моделей.
\end{abstract}

Ключові слова: Камчатка, адвекційно-поліморфна гіпотеза, швидкісна, теплова, щільнісна і геоелектрична моделі верхньої мантії.

Introduction. Pacific transition zones or in other words active continental margins have intermediate characteristics of the composition and structure between continent and ocean. These specific properties have a reflection in geophysical fields, which detailed analysis together with geological data may answer one of the most debatable questions of present geodynamics — origin of these objects.

Comparison of results of geophysical investigations with hypothetical deep processes in tectonosphere of the Earth is carried out with the help of methods that may be divided into two groups. The first group includes approaches where physical properties of crust and mantle material in the first approximation model, created according to chosen hypothesis, are changed until reaching an agreement between calculated geophysical fields (gravitational, magnetic, heat flow field) and observations or existing models (seismological, geoelectrical). If parameter changes have sense from geophysical point of view, then one 
may demonstrate that the hypothesis doesn't contradict with geophysical data. The second group includes methods that allowed construction of hypothetic model and its direct comparison (without parameters matching) with geophysical fields and models. Differences should be explained by uncertainties of model computation. Of course, the second group of approaches more efficiently controls the hypothesis, which, from the other hand, should provide a possibility of computation of distributions of physical properties that with acceptable accuracy relate to the process. Such kind of calculations became possible with the help of advection-polymorphous hypothesis (APH) applied to deep processes [Gordienko, 2001a, 2017; Sergeyev et al., 1992 and other]. In this paper we are presenting results of correlations of the hypothesis with seismological model of the East Kamchatka. As an intermediate result the heat model of the region that is controlled by geological data and gravity model is calculated.

Seismological model. Kamchatka peninsula is a part of the northeastern margin of Kurile-Kamchatka arc and the area of its junction with Aleutian arc. Seismicity of Kamchatka and adjacent of the water area is mainly concentrated in the seismic focal zone (SFZ), which extends under the peninsula to a depth of $200 \mathrm{~km}$ in the north to $600 \mathrm{~km}$ in the south. Main concentration of hypocenters is within a $60 \mathrm{~km}$ width belt that expanded along the eastern coast peninsulas. This belt indicates the place of rise of the central part of focal zone on the Earth's surface. Moving away from SFZ axis to the east and west seismic activity decreases. On the south it merges with Kuriles arc focal zone and on the north reaches Govena Island to the north of the arcs junction area. Geometry of SFZ, location of earthquake sources and their relationship with volcanic activity is discussed in detail in [Fedotov et al., 1985]. There was revealed clear dependence of earthquake distribution with lithosphere velocity structure of the East Kamchatka region [Gontovaya, Nizkous, 2005; Nizkous et al., 2006]. As a rule, higher seismicity level within bounds of SFZ is correlated with high gradient velocity zones that were found both in mantle wedge and the Pacific plate (Fig. 1). At the same time, it is evident that there is a consistency between SFZ geometry change and velocity structure.

It is the first time when it was managed to show asthenosphere wedge in mantle layer beneath volcanic belt at $70-110 \mathrm{~km}$ depth as well as intensive low velocity anomaly, which top is located at $150-200 \mathrm{~km}$ depth. This anomaly is characterized by practically total absence of seismicity and corresponds to the Central-Kamchatka Rift area on the surface. High spatial resolution tomography reconstruction [Kissling et al., 1994 and others] of the East Kamchatka lithosphere velocity structure demonstrates clear relation of mantle structure with subsurface structure and may be used to control model of deep processes in the given region.

The sequence of model comparison. Model of deep processes in alpine geosyncline of East Kamchatka and selection of size of studied region (that takes into account processes in West Kamchatka and northwestern part of the Pacific plate) are based on geological information; ages of magmatism, sedimentation and folding that are taken to be equal for all the area of investigation.

Of course, it is necessary to compare such modeling results with adequate mantle velocity profile. Location of the vertical cross-sections, those show lithosphere velocities (Fig. $2)$, demonstrates their different position in Kamchatka tectonic structure, which is reflected in velocity models. Profiles 5 and 6 are in the area of activated in alpine time Cimmerian Okhotsk See plate of near its bound [Goryachev, 1966; Marakhanov, Potapyev, 1981 and others]. So the lithosphere model should differ from that one in the area of profile 7, 8 and 10 locations. Therefore we are not considering 5 and 6 profiles data. Computation showed that the influence of Cimmerian processes beneath the Okhotsk See plate on the heat distribution model in the profile 7 area is negligible.

Differences in profile 7, 8 and 10 velocity models are probably caused by evolution specifics of each part of the region that are not accounted for in the assumed unite scheme of 


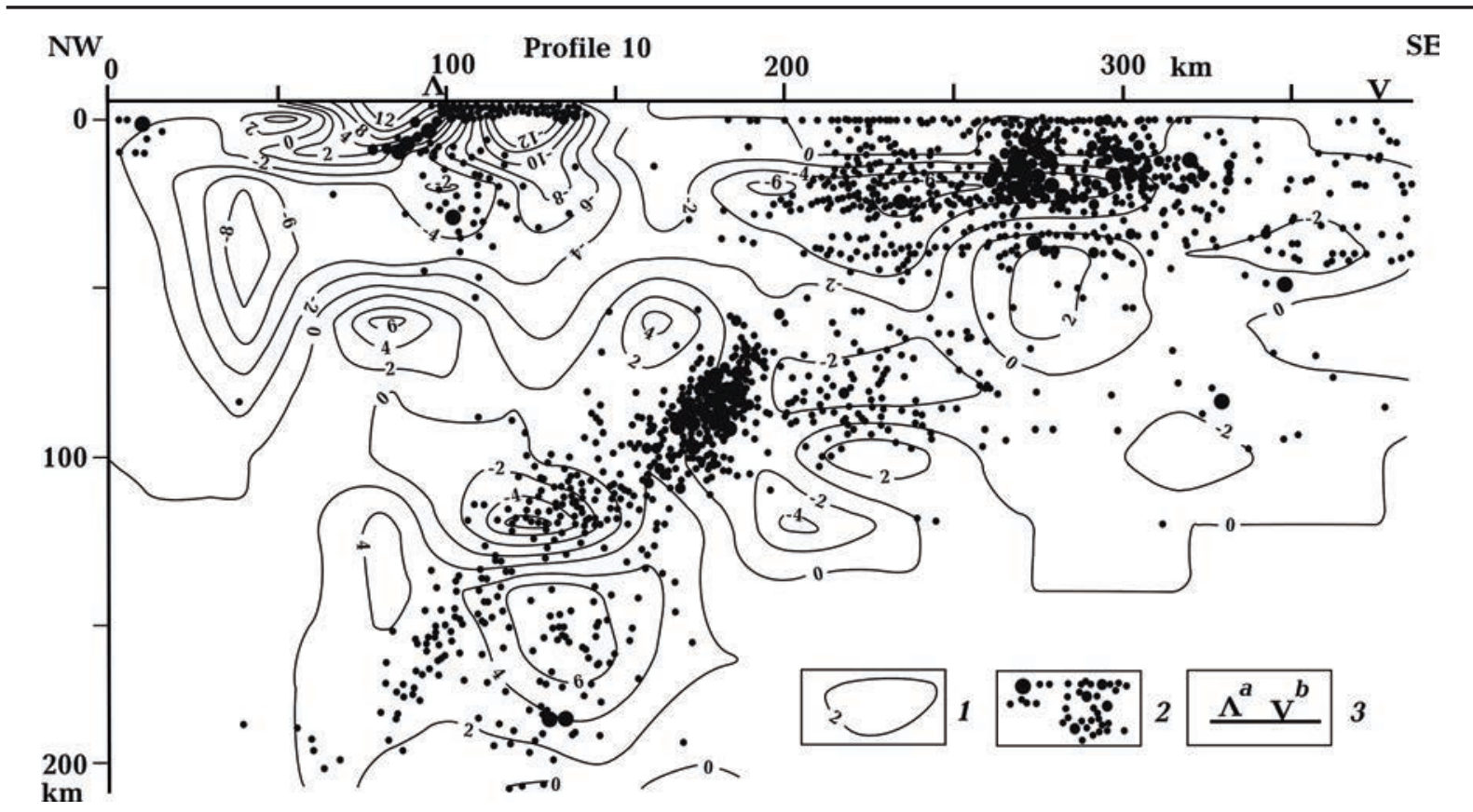

Fig. 1. Vertical cross-sections of 3D velocity model of the East Kamchatka lithosphere: 1 - $P$-wave velocity change relative to average $1 \mathrm{D}$ velocity model (contour digitization after $0.1 \mathrm{~km} / \mathrm{s}$ ); 2 — earthquake hypocenters with energy class $10-13 ; 3$ - volcanoes $(a)$, deep water trench $(b)$.

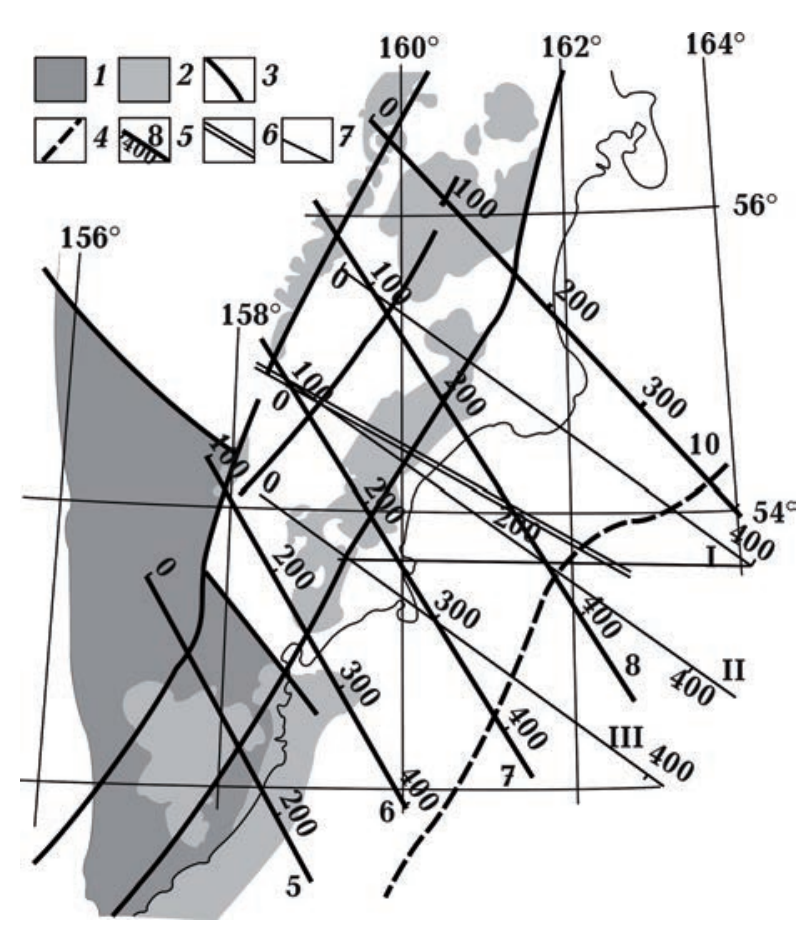

Fig. 2. Schematic geological map and mantle velocity cross section profile position: 1 - activated area of the Okhotsk Sea part; 2 - young effusive rocks; 3 - main faults; 4 - the axis of trench; 5- seismic profiles; 6 - summary interpretation profile; 7 gravity modeling profiles. geological structure. They can be investigated in the more detailed study provided with all required information. In the present work for comparison with calculated heat distribution model profile we use averaged velocity structure of these three profiles. This averaged model was created in the following way. We aligned profiles using the points where the Central-Kamchatka fault, bonding geosyncline from the west, crosses them. Vertical cross-sections represented $P$ wave velocities anomalies are parameterized by square cells $20 \mathrm{~km}$ by $20 \mathrm{~km}$ along depth and spatial axis. Cell size is chosen according to minimum volume of mantle material that moves involving in active process (see below). In each square cell the mean $P$ wave velocity anomaly $\Delta V_{P}$ is calculated, than obtained result is averaged and summed with background regional $V_{P}$ values for each depth (Fig. 3,4).

Such calculated model of average velocity is limited from the top by $50 \mathrm{~km}$ depth and by corresponding velocity isoline $V_{P}=7.5 \mathrm{~km} / \mathrm{s}$, that by convention is taken as crust-mantle boundary [Gontovaya, Nizkous, 2005; Nizkous et al., 2006]. According to other data there 
are areas on Kamchatka peninsula, where crust thickness is more then $40 \mathrm{~km}$ [Anosov et al., 1978; Marakhanov, Potapyev, 1981; Sergeyev et al., 1992 and others]. On the composite profile horizontal axis ticks show the distance normal to the geosyncline boundary rather then along the profiles 7,8 and 10. This model can be used for comparison with calculated one. But the contrast range of velocity distribution is considerably lower

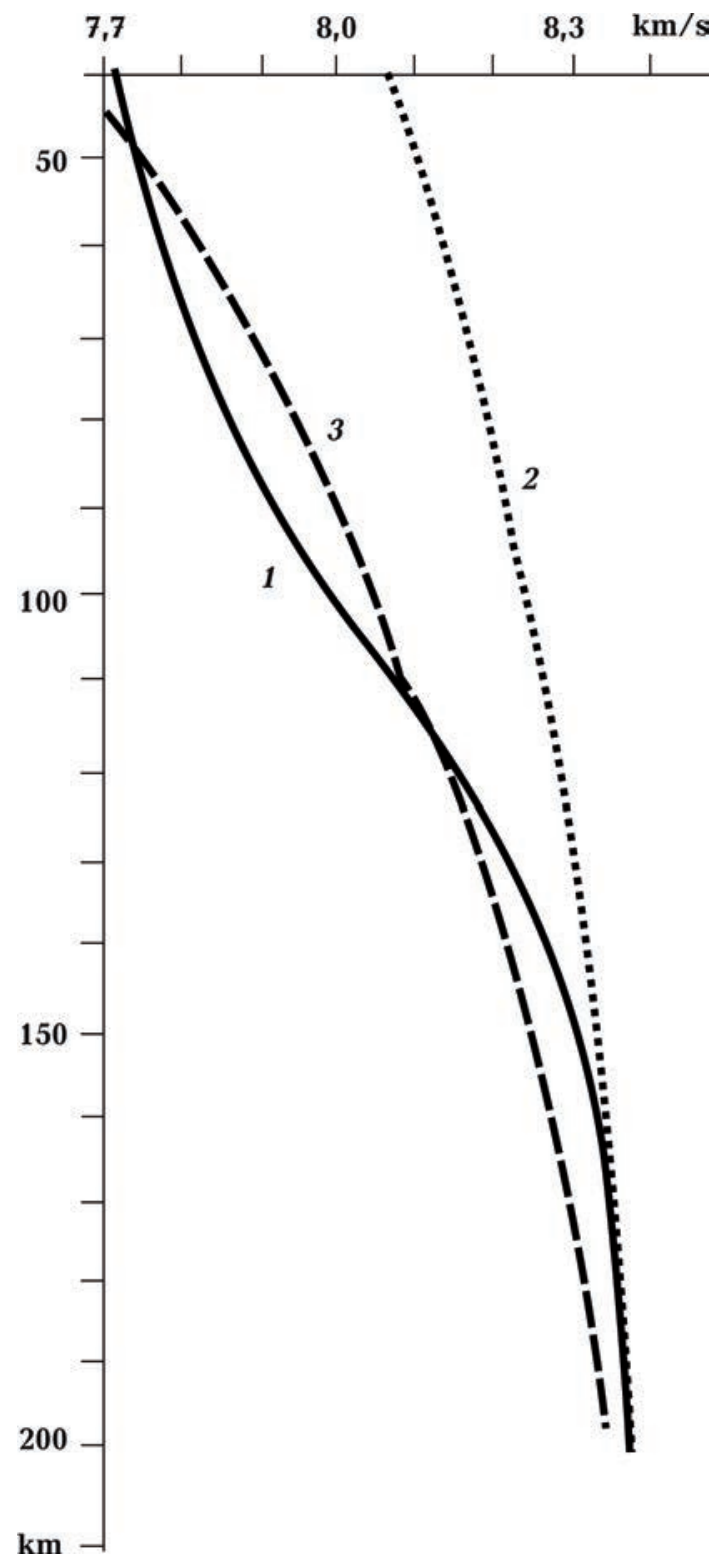

Fig. 3. Average $P$-wave velocity $V_{P}$ distribution: in the region (1), beneath Pre-Cambrian platform (2) [Gordienko, 2017 and others] and at the mantle rocks solidus point (3) (see below).

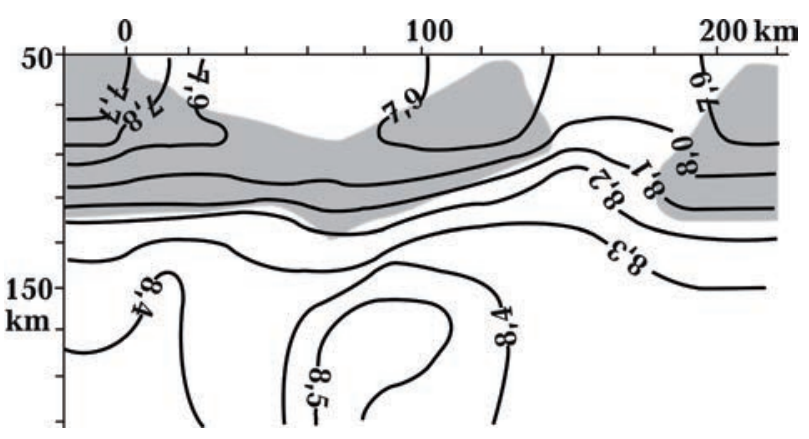

Fig. 4. P-wave velocity distribution along interpretation profile. Asthenosphere is marked with grey color.

than on particular for single profiles. However the differences in $V_{P}$ between various parts of model are noticeable and exceed $0.2 \mathrm{~km} / \mathrm{s}$ at the same depth (see Fig. 3). Asthenosphere, in other words the interval where velocities are lower than in solidus point, can be seen as well.

Advection-polymorph hypothesis. Foundation and main ideas of the hypothesis are in the following paper and monographs [Gordienko, 2001 a, 2017 and others]. This hypothesis was used many times for quantitative explanation of geological history and physical fields in the different continental, oceanic and transition zone's regions. Briefly, the summary of proposed processes is as follows. As a result of relatively long period (in the Phanerozoic) of thermal energy accumulation in the upper mantle, caused by radiation heat generation, at depths of about $220-260 \mathrm{~km}$ to $440-480$ $\mathrm{km}$ the asthenosphere is formed. Then, overheated and partly melted material is rapidly brought into the depth interval above the asthenosphere. Beneath the active region the portions of the material that have isometric forms with about $60 \mathrm{~km}$ diameter are moved. These portions of material are named as quanta of tectonic action (QTA). The floating QTA is replaced by lowering of relatively cold material from above. The order of replacement is different beneath geosynclines and rifts. For geosynclines processes it is typical when QTA's are formed within the bounds of whole asthenosphere and accompanied by mixing of asthenospheric material. The first QTA floats (synchronously with initial magmatism) into 
$160-220 \mathrm{~km}$ depth interval and is replaced by the comparatively cold material outside the active region. This process causes the temperature $(T)$ decrease near future geosyncline. Asthenosphere is shortened or disappeared here and later on there are no or restricted number of such lateral displacements. The second QTA goes up into the $100-160 \mathrm{~km}$ depth interval, lowering cold material substantially cools the asthenosphere and its top and bottom move up. The third QTA lifts (directly before the folding) to $40-100 \mathrm{~km}$ depth and due to forming subcrust asthenosphere the mantle melting material comes to the crust and replace its lower and middle part of eclogite basic rocks. Then starts the period of relaxation of heat disturbances, lowering of asthenosphere's roof layer. The last process is frequently accompanied by additional intrusions of mantle melting material into the crust (post-geosyncline activation). Both stages of intrusion result in forming the layer of partial melting in the crust and coming of crust magmatism products into the upper crust and on the surface.

Deep processes and heat distribution model. A method of deep processes modeling within the bounds of advection-polymorphic hypothesis has been substantially changed since the first time applied to Kamchatka peninsula [Sergeyev et al., 1992]. Now it allows taking into account more and much detailed geological data about single geosyncline evolution.

The scheme of deep processes and evolution of heat distribution model at the northwestern edge of the Pacific plate agrees with one described in [Gordienko, 2001a, 2017] and would not be explained here. Obtained deep values of temperatures $T$ are included in general model. Also we modeled processes in West Kamchatka geosyncline (west from marker 0) and their influence was taken into account in the heat distribution model showed on the profile.

Construction of Kamchatka deep processes scheme is similar to the work made for Carpathian Mountains [Gordienko et al., 2011]: in both cases it is necessary to consider two alpine zones with a little bit different ages of geosyncline events located near to each other. We are assuming that widths of Western and Eastern zones of Kamchatka are approximately the same - $240-250 \mathrm{~km}$ (in other words the size of zones is divisible by the width of QTA and both parts consist of about four quanta of tectonic action). On the west the process started about 140 million years ago and finished about 60 million years ago. On the east the start and the end of the process correspond to 120 and 20 million years ago accordingly [Goryachev, 1966; Marakhanov, Potapyev, 1981; Sergeyev, 1992 and others]. On the first stage of the process in the West Kamchatka region the lateral heat and mass carrying over involves the interior of future East Kamchatka geosyncline, $0-120 \mathrm{~km}$ profile markers. This causes substation differences in QTA forming in the two parts of this region. Events occurred beneath the Pacific plate noticeably influence the processes evolution on the eastern part of the profile.

Material moves from the depth intervals were QTA could be formed (this means that asthenosphere already existed at the moment of QTA forming) to standard for geosyncline process depth intervals above asthenosphere [Gordienko, 2017]: 1) 120 million years ago the material moved to the area of $0-100 \mathrm{~km}$ profile markers from the depths of about 330 $480 \mathrm{~km}$ and to the region of $100-200 \mathrm{~km}$ profile markers from depths of $260-460 \mathrm{~km}$ to the $160-220 \mathrm{~km}$; 2) 80 million years ago material moved to the area of $0-100 \mathrm{~km}$ profile markers from $380-480 \mathrm{~km}$ and to the region of $100-170 \mathrm{~km}$ profile markers from the depths of $180-260 \mathrm{~km}$ to the $100-160 \mathrm{~km}$ depth; 3) 20 million years ago material moved in the following way: to the area of $0-80 \mathrm{~km}$ profile markers from the depths of $120-190$ $\mathrm{km}$, to the 80 - $120 \mathrm{~km}$ profile markers - from 120 - $180 \mathrm{~km}$ depth interval, to the $120-160$ $\mathrm{km}$ profile markers from the depth interval of $140-180 \mathrm{~km}$ and to 180 - $240 \mathrm{~km}$ profile markers from $440-480 \mathrm{~km}$ depth to the $40-100$ $\mathrm{km}$ depth interval. Time of QTA lifting was approximately assessed, and in future during more detailed analysis of geosyncline geological history it may be defined more precisely. All the profile regions (except the most eas- 
tern one with thin crust) the last stage of tectonic process supplied with crust intrusions at about 20 -40 km depths. During last several million years there is a modern activation of the territory of Kamchatka. In the model it is represented by carrying-out of melting material from the residual asthenosphere to the 0 - $20 \mathrm{~km}$ and 40 - $80 \mathrm{~km}$ profile markers 5 and 0.5 million years ago [Marakhanov, Potapyev, 1981 and others].

Each material movement resulted in formation of temperature anomaly zones of different signs at different depths. They were considered as non-stationary three-dimensional source of heating and their effect has been calculated during the whole time interval starting from the moment of appearance till the present time. Temperature anomalies were summed with background temperature $T$ that existed before active process.

The result from heat distribution model is represented in Fig. 5. This model includes mantle astenosphere at about $70-120 \mathrm{~km}$ depth (that can be explained by exceeding of solidus temperature $T$ ) and the thin layer of partially melting material in the crust at about $20-30 \mathrm{~km}$ depth that previously was expected at temperatures higher then $600{ }^{\circ} \mathrm{C}$. The absence of the both layers is possible in the interval of $130-170 \mathrm{~km}$ profile markers. And it seems to be probable the existence of small layer of partial melting in the bottom of the most warmed-up part of the thickest crust at temperatures $T>1050{ }^{\circ} \mathrm{C}$.

The crustal part of heat distribution model was calculated in the most general way without possible detailed elaboration [Gordienko, 2017] that takes into account rather complex processes in the crust interior that is typical for post-geosyncline activation.

Verification of the heat distribution model with the help of geological data. 1. Information about temperatures and pressures (depths) of formation of crustal rocks that are on the surface at present time [Marahanov, Potapyev, 1981; Frolova et al., 1989; Sergeyev et al., 1992 and others] allows to control the crustal part of the heat distribution model (Fig. 6). In general all the data are in good agreement. Exceeding of experimental
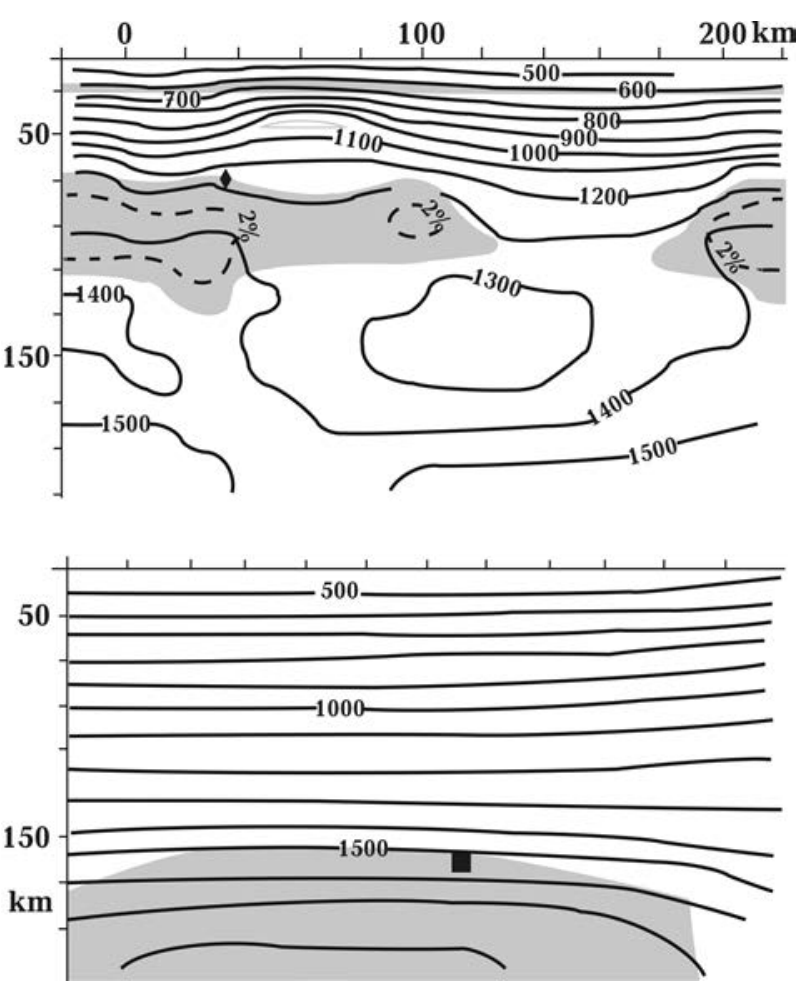

Fig. 5. Heat distribution model (isotherms are in ${ }^{\circ} \mathrm{C}$ ) along the profile. Upper figure is modern model, bottom figure - 100 million years ago. Grey color is used to show layer of partial melting of the material, dashed line is boundary of the region where melt concentration in higher then $2 \%$, black rhomb and square mark sources of magmatism.

measured temperatures $T$ above calculated temperatures in some regions caused by depth interval above the layer of partial melting in the crust. High temperatures reflect heating of the crust rocks in the areas of magma intrusions. This magma intrusion element of the entire process is not considering in the model, but when analyzing local temperature anomalies can be explained [Gordienko, 2017 and others].

2. According to petrologic data [Frolova et al., 1989] depths of the sources of relatively young magmatism in the Kamchatka mantle may be located at depths of about $70 \pm 10 \mathrm{~km}$ to $140 \pm 20 \mathrm{~km}$. This result is in a good agreement with recent heat distribution model (see Fig. 5).

3. Available information about Kamchatka mantle rock composition and conditions of their melting allow suggesting that the melt- 


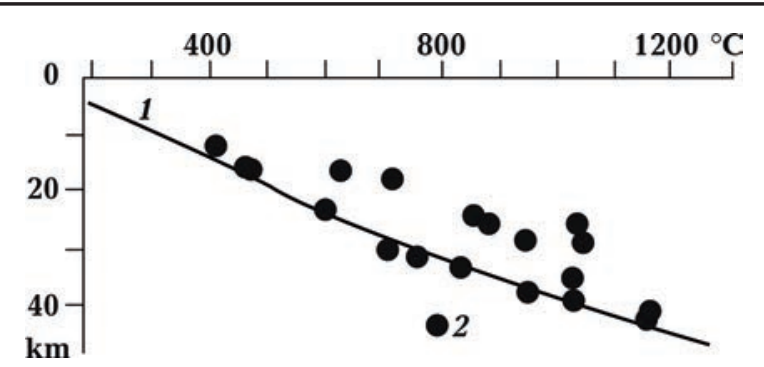

Fig. 6. Comparison between calculated (1) and experimental (2) temperatures in Kamchatka crust.

ing element is lherzolite under high fugacity of oxygen [Volynets et al., 1999 and others]. That is why it is possible to use experimental data concerning composition of melting material at different depths [Kadik et al., 1990] for determination of the source (melting material differentiation) depth. Usually it locates near upper boundary of asthenosphere that exists at the moment of magmatism process. The ma- in role in source depth determination is played by the values of aluminium and magnesium oxidizes in the magma material (Fig. 7).

Results of comparison show that the depth of the present asthenosphere top in the corresponding area of young magmatism is about $72 \pm 16 \mathrm{~km}$ (see Fig. 7). We are using the data concerning compositions of basalt, andesite-basalt, andesite and absarokite according to [Gordienko, 2017]. The obtained depth correlates with position of the top of asthenosphere on the profile. Picrites and meymacites of Valagin series, which age is about 100 million years [Seliverstov, Tsykunov, 1974; Rass, Frih-Har, 1987] were melted out at the depth of about $165 \pm 13 \mathrm{~km}$. In this case information about $\mathrm{Na}_{2} \mathrm{O}(0.1-0.2 \%)$ content was not taken into account when determining the source depth because of negligible concentration of this oxide. The obtained result correlates with the depth of the asthenosphere top of the corresponding age (see Fig. 5).
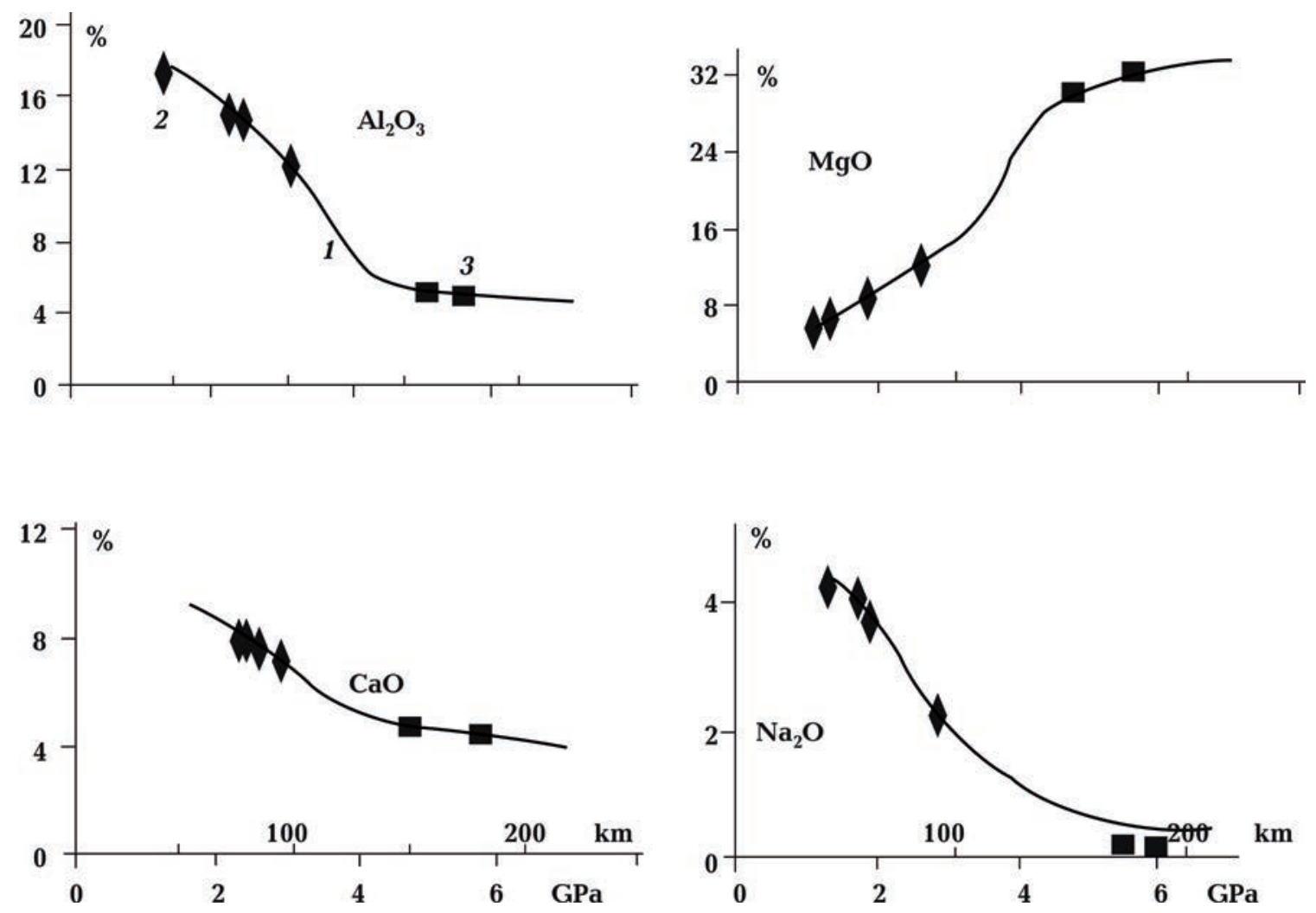

Fig. 7. Comparison of melt composition at different depths of mantle (1) [Kadik et al., 1990] with composition of Kamchatka igneous rocks of different ages (2) [Volynets et al., 1999] and (3) [Seliverstov, Tsykunov, 1974; Rass, Frih-Har, 1987]. 
4. Another method for determining the depth of the magma source and the temperature in it gives for the last stage of the geosynclinal process in Kamchatka (and island Paramushir) values are $55 \mathrm{~km}$ and 1200 ${ }^{\circ} \mathrm{C}$ and $90 \mathrm{~km}$ and $1350{ }^{\circ} \mathrm{C}$ [Gordienko, 2017 and others].

Thus we may consider that there is a good control of the heat distribution model from petrology information. Using additional data about composition of igneous rocks of mantle origin and different age from other areas of Kamchatka may be useful for further improving of the heat model.

5. The scheme of deep process corresponding to the APH allows one to calculate the thickness of the young sedimentary layer. In the case of Kamchatka, it turns out to be about $6 \mathrm{~km}$. The available data reveal a close average value (Fig. 8).

6. It seems reasonable to control the heat distribution model by regional heat flow [Smirnov et al., 1991]. But in practice it is not so effective. Heat flow values are mainly determined by temperature distribution in the upper crust corresponded to the latest processes of mass and heat transfer in the limited depth

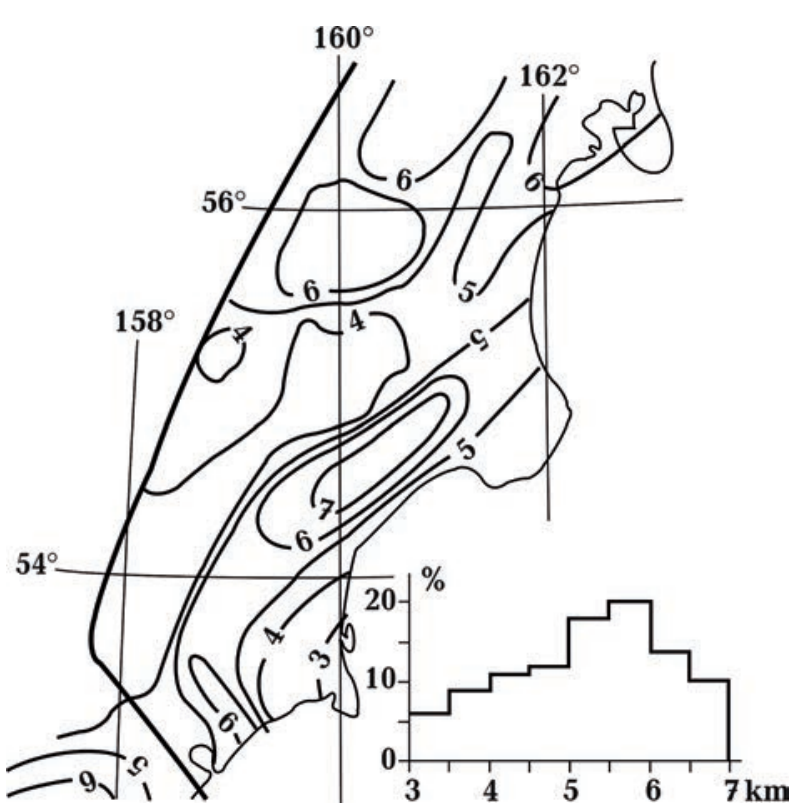

Fig. 8. Scheme of thickness $(\mathrm{km})$ of the sedimentary layer of East Kamchatka and bar graph of its distribution.

Геофизический журнал № 1, Т. 42, 2020

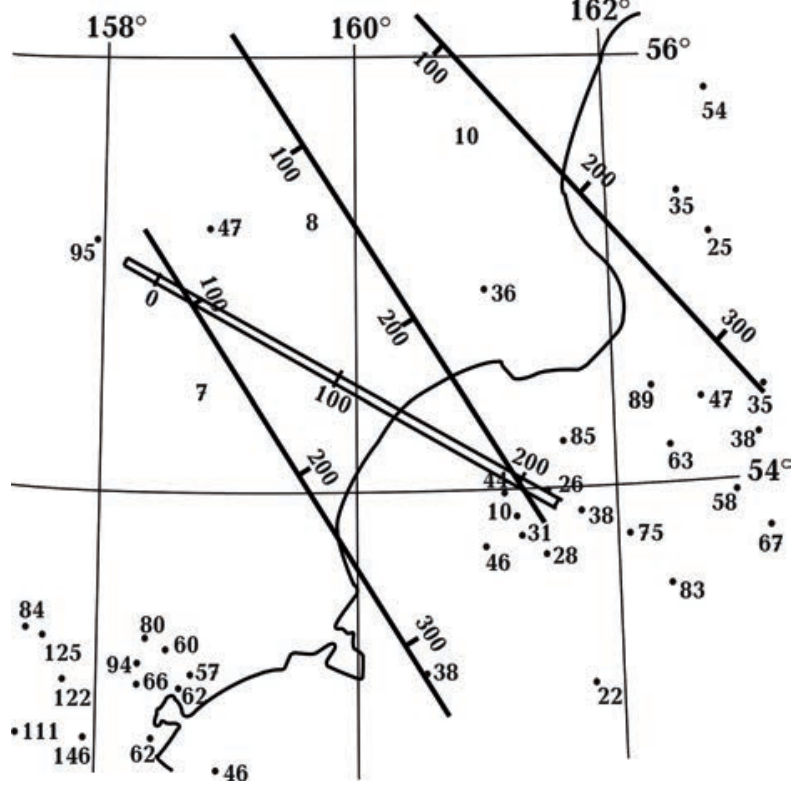

Fig. 9. Heat flow distribution $\left(\mathrm{mW} / \mathrm{m}^{2}\right)$ in the area of study [Smirnov et al., 1991].

interval. In our case it is impossible to control heat distribution model using heat flow data because of lack of geothermal information for Kamchatka peninsula (Fig. 9).

Calculated velocity model. Based on the heat distribution model, in other words using the temperature difference between background values beneath Precambrian platform and the values at different depth, and information about velocity distribution in Precambrian platform mantle that correlate with convention hypothesis and lherzolite composition of mantle rocks, pressure wave velocities $V_{P}$ were calculated. These computed $V_{P}$ were compared with experimental values. At present time the character of temperature variation of $P$ wave velocity at different depths is well investigated, see for example [Sobolev et al., 1996]. For calculations the temperature function of $P$ wave velocity, $V_{P}=f(T)$, was simplified to linear dependence, which result in uncertainty less then $0.01 \mathrm{~km} / \mathrm{s}$. We consider that $100{ }^{\circ} \mathrm{C}$ temperature difference from the background values (beneath the platform) leads to $0.06 \mathrm{~km} / \mathrm{s}$ change of the $P$ wave velocity, $V_{P}$. Presence of melting material, when mantle rock solidus temperature $T_{\mathrm{C}}$ is exceeded, where $T_{\mathrm{C}}=1013+3.914 \mathrm{H}-$ 


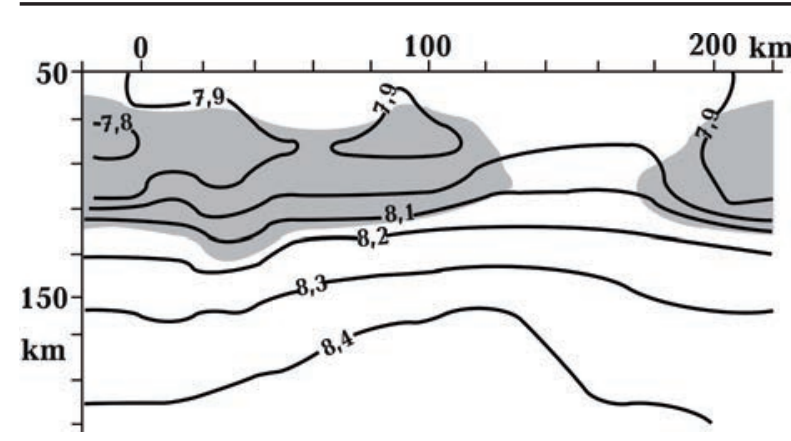

Fig. 10. The calculated velocity model along the profile. Grey color shows asthenosphere location.

- $0.0037 H^{2}$, where $H$ - is depth in $\mathrm{km}$, introduces additional $0.07 \mathrm{~km} / \mathrm{s}$ decrease of $V_{P}$ values for each percent of its concentration. It was supposed that the quantity of melting material increases by $1 \%$ with every $50^{\circ}$ degrees of temperature rise starting from $1 \%$ at the solidus point.

Calculated velocity model along interpretation profile is shown in the Fig. 10. It is clear that we have elements that coincide with experimental model and differ from it. Comparing calculated velocities $V_{P}$ with average $P$ wave velocities for each depth (Fig. 11, a) one can see that computed velocity is slightly lower than experimental one, except the most top part of the cross-section.

Results of comparison of $V_{P}$ values for $20 \mathrm{~km} \times 20 \mathrm{~km}$ squares for given profile are showed in Fig. 11, b. Distribution of anomalies slightly differs from the normal one, but modal value assessment $(0.075 \mathrm{~km} / \mathrm{s})$ is rather reliable and could probably be explained by uncertainties of both compared values and computation error is more then $0.05 \mathrm{~km} / \mathrm{s}$. Thus we can conclude that there is a good agreement between velocities.

Heat distribution model and seismicity. Heat distribution model that reflected deep processes in the region should take into account another important parameter, namely seismicity. Earthquakes in mantle may be caused by displacements of QTA, magma movement, temperature change, when critical stress is exceeded by thermo-elastic one, rock blocks shift due to density change, polymorphous transformation of bottom part of upper mantle material. The latest displacement of QTA according to assumed scheme of process occurred 0.5 million years ago and the magma movement caused by this replacement was

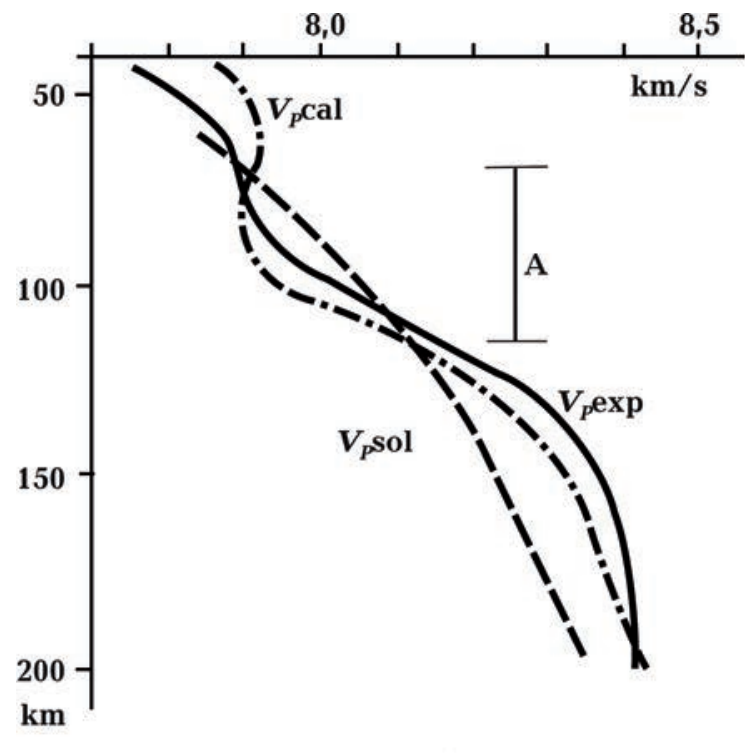

a

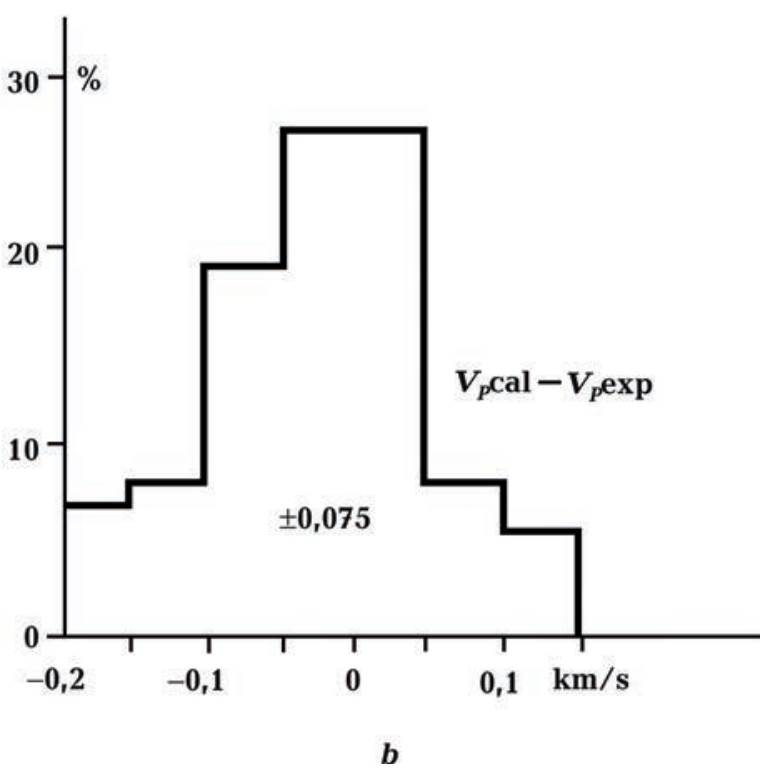

Fig. 11. Comparison between average calculated and experimental velocities on the profile: $a$ - asthenosphere (A) according to seismology and geothermal data; $b$ - histogram of differences of calculated and experimental $P$ wave velocities $V_{P}$ on the profile. 
predicted in general without determination of specific place and time. Polymorphous transformations occurred in the depth interval out of limits of considered models. That is why we consider thermo-elastic stress and density change.

We compare mantle earthquake hypocenters location beneath profiles 7, 8 and 10 with mentioned above parameters according to the following scheme: we determine average number of hypocenters in squares $20 \mathrm{~km} \times 20 \mathrm{~km}$ of the cross section beneath interpretation profile [Gordienko, 2017; Sobolev et al., 1996], and using this data we draw earthquake concentration isolines presented in Fig. 12.

Then obtained results are compared with temperature variation data at different depths of the mantle that occurred during the last hundreds of thousand years. Finally it was found that there is no visible interconnection between maximum earthquake hypocenters concentration and maximum temperature change. Probably thermo-elastic stresses do not play significant role in the areas of high seismic activity, like Kamchatka. In the other regions of present day active tectonic processes with the help of thermo-elastic stress information it was possible to explain only the existence of zones with minor concentration of seismic events [Gordienko, 2017 and others].

Density changes that occurred during deep active processes in the mantle of East Kamchatka were calculated using anomaly temperatures. It was considered [Sobolev et al., 1996; Gordienko, 2017 and others] that density change is $0.013 \mathrm{~g} / \mathrm{cm}^{3}$ when temperature is changed by $100{ }^{\circ} \mathrm{C}$; and $1 \%$ of the melting material decreases the density by $0.003 \mathrm{~g} / \mathrm{cm}^{3}$. For each depth average density was calculated and determined the variation from this mean value (Fig. 13).

One can see that there is a qualitative similarity of density and earthquake concentration distribution. Relatively dense inclined block of rocks could produce stress result in generation of seismic events. To analyze it, it is necessary to consider numerous parameters of the medium and earthquake characteristics. Probably, the main role is not played by thermal effects, but by the descent of crust eclogi-

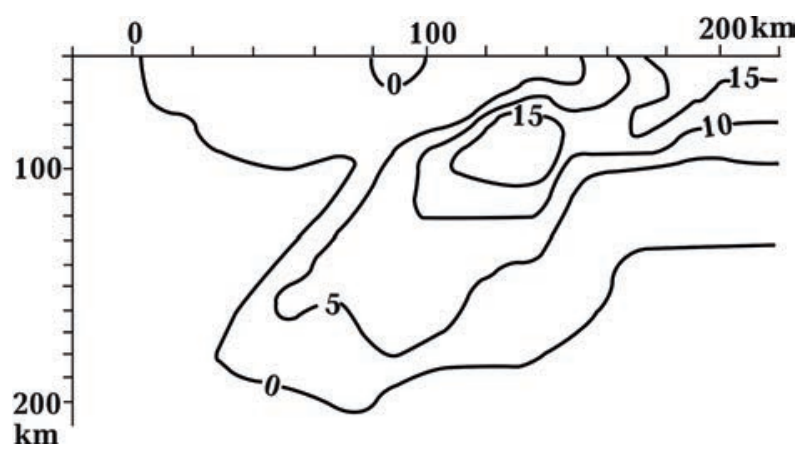

Fig. 12. Distribution of hypocenters of mantle earthquakes selected from Kamchatka catalogue for 3D lithosphere velocity model calculation.

tic blocks into the mantle [Gordienko, 2014 and others].

Earthquakes with depths of foci reaching about $250 \mathrm{~km}$ may well be accounted for by downwarping of eclogitized crustal blocks that started earlier at the rear flanks of the geosyncline where it reached maximum. In the frontal part of the region, the process started recently, and subsidence there is minimal. Beneath western Kamchatka, where there lies an Epi-Cimmerian or Late Alpine plate, the process is most likely over and earthquakes are rare. Deeper earthquakes can only strike in the zone of transition to the lower mantle. Their hypocenters are separated from shallower ones by an extensive aseismic gap. Such gaps exist in all regions where earthquake foci are located in the zone of polymorphic transformations.

According to [Balakina, 2002], the mechanisms of the aforementioned earthquakes

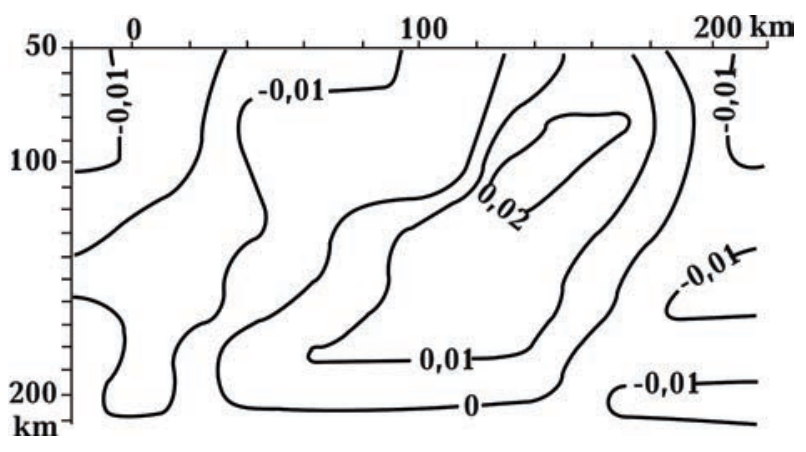

Fig. 13. The density anomalies of mantle rock beneath the profile (in $\mathrm{g} / \mathrm{cm}^{3}$ ). 
are associated with verical displacements of tectonic blocks. In tems of the advection polymorpism theory (APH), at larger depths (over $600 \mathrm{~km}$ ), that is in the zone of transition to the lower mantle (like in the case of the 2013 earthquake in the Sea of Okhotsk, east of Kamchatka), the character of earthquakes is different. What actually happens there is a change in the rock volume resulting from the process of polymorphic transformation. Distribution of aftershocks in time may be indicative, to a certain extent, of the type of the mechanism. In this sense, the significance of the data on the earthquake in question cannot be overestimated. It has long been common knowledge that distribution of aftershocks from more shallow earthquakes obeys the Omori law. This fits a strike-slip mechanism. The Omori law does not support the case under study (Fig. 14), at least not for the initial time-related aftershock sequence of aftershocks.

Thermal model and geoelectrical data. Various publications provide somewhat different depth intervals, at which a conductive layer (with specific electric resistance $\rho$ smaller than $100 \mathrm{Ohm} \cdot \mathrm{m}$ ) lies in the mantle beneath East Kamchatka and the Kronotsky Gulf [Moroz, 1991 and others]: from 40-150 to $110-180 \mathrm{~km}$. This uncertainty can be readily explained by complicated conditions under which the deep-seated feature was iden-

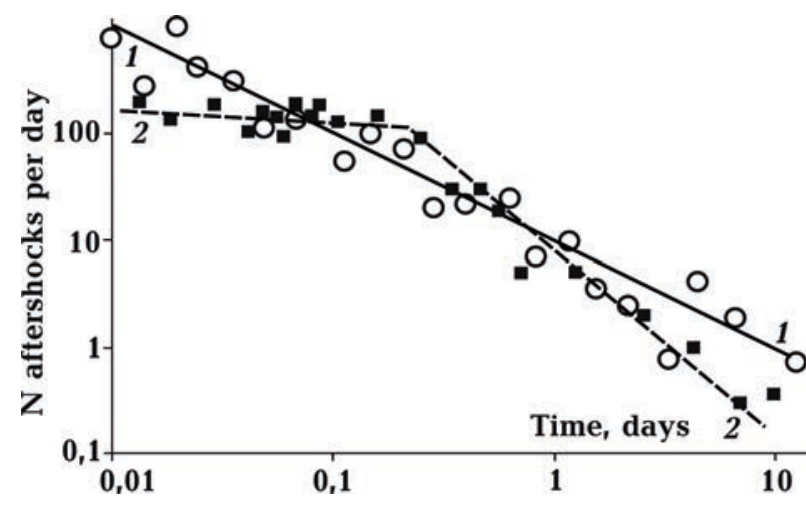

Fig. 14. Correlation between temporal distributions of aftershocks from an earthquake in the upper mantle levels in Japan [Enescu et al., 2009] and the deepfocus earthquake in the Sea of Okhotsk. Graphs for the earthquakes: 1 - in Japan, 2 - in the Sea of Okhotsk. tified beneath crustal conductive zones with variable $\rho$ and appreciable composite longitudinal conductivity.

Comparison between thermal and velocity models, on the one hand, and geoelectrical model, on the other, reveals their significant mismatch. Crustal portions are qualitatively similar. Mantle portions are not.

Differences in depths of the conductive layer's bottom are not so important. The point is that, in geoelectrical surveys, the depth of the top of the body and the magnitude of the composite longitudinal conductivity are the most reliably determinable parameters. Yet, according to geoelectrical model, $S$ amounts to 8500 - $9000 \mathrm{Sm}$ (siemens units), whereas in thermal and seismological models it ranges from 1500 to $2000 \mathrm{Sm}$.

The evaluation of $S$ for the asthenosphere on thermal and seismological models was conducted for virtually dry melting conditions and an average melt concentration of about $2 \%$. In that case, for reaching the $\rho$ value of $5-10 \mathrm{Ohm} \cdot \mathrm{m}$ in a conductive medium, the relevant concentration should be $12 \%$, which corresponds to a velocity anomaly of about $1 \mathrm{~km} / \mathrm{s}$. Such an anomaly is unlikely for a considerable depth range. Segregation of the melt and its transport upwards (resulting in a depletion of the concentration in the layer) take place at a concentration of $3-5 \%$. The value of $\rho$ may only change if the mantle melt contains a large amount of fluids. The available estimates of this parameter for Kamchatka's young igneous rocks [Frolova et al., 1989; Volynets et al., 1999 and others] do not go beyond the limits within which the effect of fluids on the asthenosphere's $\rho$ is minor [Gordienko, 2001 b]. Further studies of geoelectrical data were instrumental in establishing a $70-110 \mathrm{~km}$ depth range with high electrical conductivity in the mantle of East Kamchatka (on the whole, as an integral region) [Moroz, 2009]. The above estimate is close to the data of thermal and seismological models.

The values of $S$ were obtained for 1D and 2D models. When using a 3D model in the southern part of Kamchatka, the values of the conductivity objects in the mantle are about $2000 \mathrm{Sm}$, in individual blocks up to 5000 [Be- 
lyavsky, Aleksanova, 2014]. Thus, coordination with the thermal model seems possible.

Density model of tectonosphere. The aforementioned three-dimensional velocity model incorporates the Earth's crust. It turned out to be sufficiently detailed and reliable for constructing (in combination with other data [Anosov et al., 1978 and others]) diagrammatic models of density distribution along the three profiles running across East Kamchatka (see Fig. 2). The crustal model represented the distribution of depths for the $\mathrm{M}$ discontinuity, 6.5 and $7 \mathrm{~km} / \mathrm{s}$ velocity levels, and the basement. The velocity of a layer between the 7 and 6.5 $\mathrm{km} / \mathrm{s}$ isolines was assumed to be $6.7 \mathrm{~km} / \mathrm{s}$. The $V_{P}$ value of $6.0 \pm 0.5 \mathrm{~km} / \mathrm{s}$ was adopted for the basement surface, and $6.5 \mathrm{~km} / \mathrm{s}$ was considered as an average between the basement and the $6.5 \mathrm{~km} / \mathrm{s}$ isoline. Thus, the velocity profile used is over schematized, yet, given the available factual data, it is impossible to construct a more detailed profile: The details would be inaccurate.

The abundance of basic and ultrabasic rocks in the Earth's crust of Kamchatka has prompted us to use, alongside conventional formulas, also conversion formulas from $V_{P}$ to $\sigma$ applicable to the layer of crust-mantle mixture (CM): $\sigma=$ $=2.69+0.26\left(V_{P}-6\right)$ and $\sigma=3.02+0.28\left(V_{P}-7\right)$, where $\sigma$ is density in $\mathrm{g} / \mathrm{cm}^{3}$. It certainly largely applies to the lower layer of a consolidated crust: Without the effect of high temperature, velocity values there would have been like in the CM layer. Small corrections $\left(0.005-0.01 \mathrm{~g} / \mathrm{cm}^{3}\right)$ made up for the anomalous heating of the crust. The thickness and density $\left(2.55 \mathrm{~g} / \mathrm{cm}^{3}\right)$ of the sedimentary-igneous veneer on dry land was adopted according to a study published by [Sergeyev et al., 1992] and others. These data do not contradict the rather scanty information on seismic wave velocities in Kamchatka's veneer (2.4-4.6 $\mathrm{km} / \mathrm{s}$ ). The thickness of sediments beneath the seabed was believed to be decreasing in the direction from the shore to the trench from $4-5$ to $1-0.5 \mathrm{~km}$ in accordance with typical distributions of the parameter in other areas of South Kamchatka, as well as the Kuriles and Hokkaido. It was assumed that the density there is somewhat lower than on dry land:
$2.45 \mathrm{~g} / \mathrm{cm}^{3}$. There is no material to specify the parameter, and the influence of its variation on crustal effect is hardly significant at all.

Provided that density distribution in the upper mantle is normal, the estimated gravitational effect of the crust resembles in shape the distribution in the observed field, but as far as its level is concerned, it has nothing in common with the latter: It is higher by approximately $200 \mathrm{mGal}(170-190 \mathrm{mGal})$ on dry land and by over $200 \mathrm{mGal}$ at sea. The magnitude of the mantle anomaly generally resembles that one common for the Alpine geosyncline undergoing contemporary activation, as well as for young oceanic basins. It testifies to a very intensive heating of the upper mantle's top portion, something that (in terms of the APH) is inevitably associated with the cooling of the mantle's lower portion and polymorphic transformations of mantle rocks.

A thermal model for the upper portion of the mantle (to approximately $200 \mathrm{~km}$ ) was already presented earlier in this paper. A certain adjustment was introduced for the mantle beneath the basin. The major problem in the construction of a model for the basin encompassing the entire thickness of the upper mantle boils down to the lack of reliable geological information on the events that have taken place over recent dozens of millions of years. The problem is further aggravated by the fact that the process beneath the Obruchev Hills may differ from the processes in the basin proper. Even if temperatures in the top portion of the upper mantle are similar for different versions of the process, they may differ considerably in the mantle's lower portion and cause changes in density (which may turn out to be quite appreciable once conditions become ripe for polymorphic transformation of rocks), so that the resulting densities would differ from those used in the calculations. These considerations have prompted us to restrict the area of calculations and not to go beyond the trough axis. Further southeast the reliability of the results may sharply decrease.

The distribution of temperatures was used to determine anomalous densities. The following factors affect them.

1 . Variations in $\sigma$ relative to normal distri- 
bution $\left(T_{n}\right)$ under the effect of an anomalous temperature, i. e. its deviations from the background temperature. At the point of solidus $\left(T_{s}\right)$ the amount of fluid was assumed to equal $1 \%$, so that for its increase by $1 \%$ (to the level of segregation - presumably amounting to $3-5 \%$ ), a heating by $50{ }^{\circ} \mathrm{C}$ was assumed to be required. One percent of basaltic fluid (at depths indicated in the model) reduced the density by $0.0033 \mathrm{~g} / \mathrm{cm}^{3}$. This correlation cannot be applied to larger depths: For melt composition corresponding to the composition of the rock, the melt is more compact than the solid mantle at depths larger than 200 $250 \mathrm{~km}$.

2. High temperatures caused mantle rocks at depths from $\mathrm{M}$ to 30 and from 30 to $100 \mathrm{~km}$ to transform to plagioclase and spinel facies, respectively. This resulted in the reduction of their densities by 0.125 and $0.08 \mathrm{~g} / \mathrm{cm}^{3}$ [Gordienko, 2017 and others]. A concept regarding preservation of relics of the reworked continental crust beneath a thin oceanic crust (down to $33 \mathrm{~km}$ ) in the northwestern basin [Sergeyev, 1997] suggests the same densities.

The anomalous density values for upper mantle rocks of the region are presented in Fig. 15.

3. During the process of cooling of the upper mantle's lower portion as a result of the overlying deep-seated material sinking there, conditions arise that promote a temperature at which olivine transforms into a mineral with the structure of spinel, and thus the rock undergoes compaction by approximately 0.21 $\mathrm{g} / \mathrm{cm}^{3}$ [Gordienko, 2017 and others]. At a normal temperature distribution, the transformation occurs at the depth of about $470 \mathrm{~km}$.

Attempts to precisely determine the error in calculations of the effect of the mantle's anomalous densities have so far failed. Real errors in the calculation of temperatures enable us to assess errors in drawing boundaries of polymorphic transformation zones at just a few kilometers.

Associated with them in each case may be errors in the calculation of the field equaling $10-15 \mathrm{mGal}$.

With an account for all the errors in the determination of estimated and observed fi-

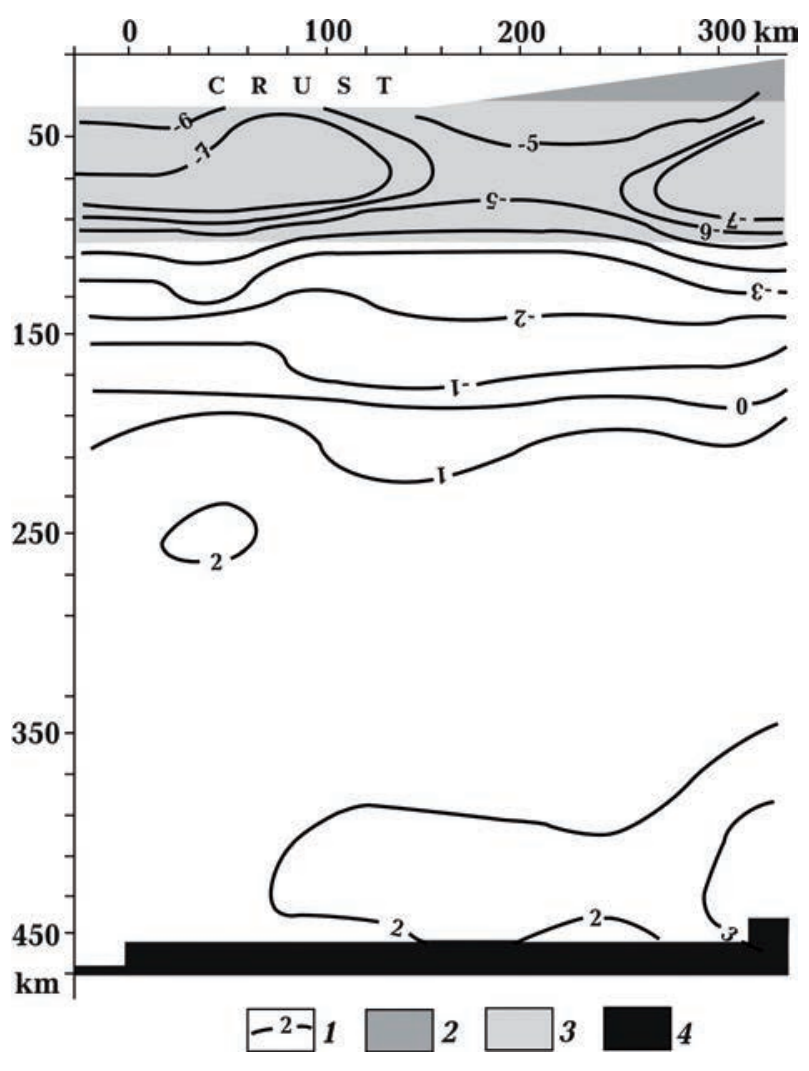

Fig. 15. Anomalous densities in the upper mantle beneath the profiles: 1 - isolines of anomalous densities (in $0.01 \mathrm{~g} / \mathrm{cm}^{3}$ ) associated with anomalous temperatures and partial melting; 2 - plagioclase lherzolite zone; 3 - spinel lherzolite zone; 4 - zone (above $470 \mathrm{~km}$ ) of anomalous compaction in connection with polymorphic transformation at the bottom of the upper mantle.

elds listed above as $\left(\Sigma(\Delta g)^{2}\right) 0.5$, we get an assessment of the divergence that they caused between the $\Delta g$ values being compared amounting to about $40 \mathrm{mGal}$. The estimated gravitational effect of anomalous densities in the upper mantle beneath the profiles makes it possible to approximately equalize the estimated and observed fields (see Fig. 13). Significant divergences have largely been detected in marine portions of the profiles where errors in the determination of both values being compared may increase. It cannot be ruled out that after the used a priori information is refined, the estimated and observed fields may turn out to be closer in magnitude. On the whole, correlation between the fields may be viewed as satisfactory, with an allowance for the lack of accuracy and, occasionally, the 
hypothetical character of the data used and colossal swings in the values of gravitational fields along the profiles.

Maximum divergences between the estimated and observed fields at some sites reach 89-100 mGal, which is a lot, yet they do not contradict the assessment made above. Maximum divergences are confined to the trough and to the area east of it. The overall results of the comparison between the fields are shown in Fig. 16.

8. It follows from them that the average difference between the fields along all the three profiles does not exceed the forecast value and amounts to 30-40 mGal. A histogram of the distribution of the divergences is more or less symmetrical and points to its relative similarity to normal distribution (Fig. 17).

We can generally claim that in the case of Kamchatka, a fairly good match between

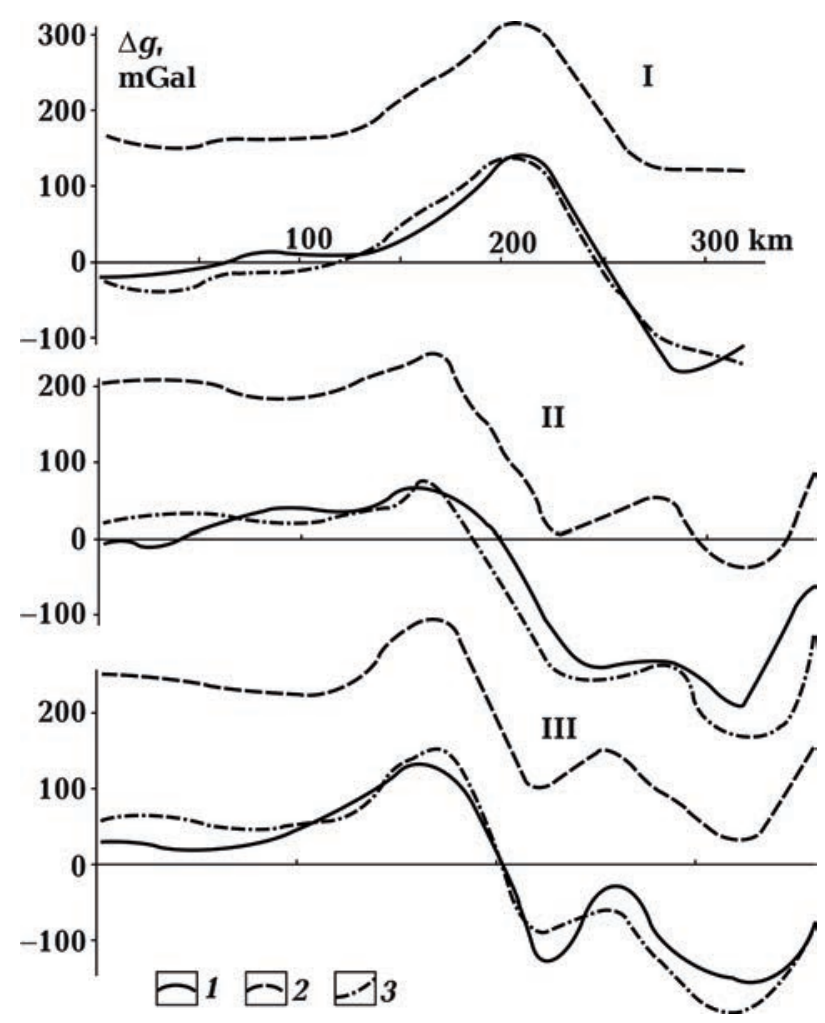

Fig. 16. Comparison between estimated and observed gravitational fields along profiles I, II, and III (see Fig. 2): $1-3$ gravitational fields (1-observed, 2 and 3 estimated $(2$ - the effect of the crust and normal mantle, 3 - taking into account the mantle's anomalous density)).

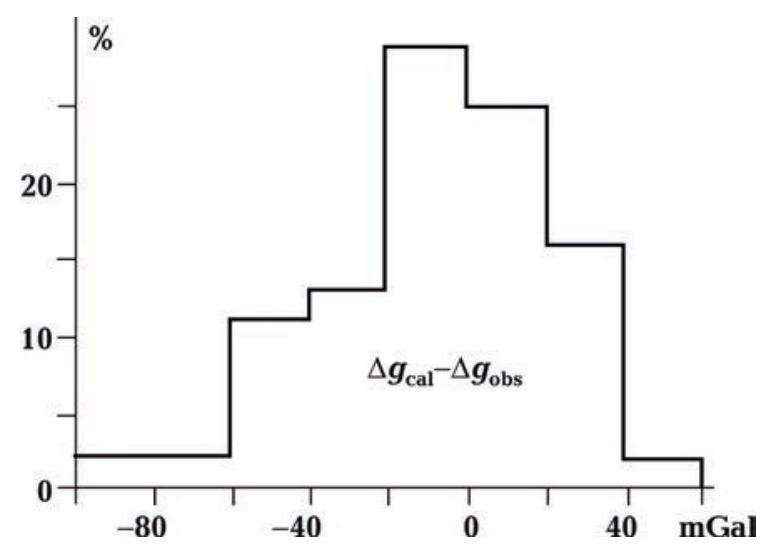

Fig. 17. Histogram illustrating divergences between calculated and observed fields along profiles I, II and III.

prognostic and experimentally derived parameters can be achieved without the need to adjust them, and the level of deviations is in line with errors in both sets of parameters.

Conclusions. Results of high resolution seismic tomography focused on construction of lithosphere velocity model for continentocean transition zone in the East Kamchatka region revealed series of characteristic features of deep structure of this zone as well as the Pacific plate. It was shown that this velocity model is in a good agreement with theoretical velocity profile calculated for upper mantle (50-200 km depth interval) based on advection-polymorphous hypothesis.

The location of the region of elevated values of $V_{P}$ in the velocity section of the region does not allow connecting it with the oceanic plate sinking into the subduction zone. In accordance with the concepts of lithospheric plate tectonics hypothesis, this object (and the earthquake hypocenters accompanying it) should be located approximately $50 \mathrm{~km}$ east, behind the axis of the Kuril-Kamchatka trench.

It was developed a heat distribution model of the region that is controlled by additional geological data. The result of comparison of geophysical and petrological data allows us to say that sources of young magmatism correspond to asthenosphere layer in mantle the 70 - $120 \mathrm{~km}$ depth interval.

According to the thermal model of the up- 
per mantle, density model is constructed. Its effect quite fully explains the mantle gravitational anomaly in Kamchatka.

Aligning the results of geoelectrics with the thermal model is not so complete. But recent data point to the possibility of achieving it.

We can generally claim that in the case of Kamchatka, a fairly good match between prognostic and experimentally derived parameters can be achieved without the need to adjust them, and the level of deviations is in

\section{References}

Anosov, G. I., Bikkenina, S. K., Popov, A. A., Sergeev, K. F, Utnasin, V. K., \& Fedorchenko, V.I. (1978). Deep seismic probing of Kamchatka. Moscow: Nauka, 130 p. (in Russian).

Balakina, L. M. (2002). Subduction and Mechanisms of Earthquakes. In Controversial Aspects of Plate Tectonics and Possible Alternatives (pp. 120-141). Moscow: Edition of the Institute of Physics of the Earth of the Russian Academy of Sciences (in Russian).

Belyavsky, V.V., \& Aleksanova, E.D. (2014). Three-dimensional geoelectrical model of southern Kamchatka. Fizika Zemli, (1), 11-32 (in Russian).

Enescu, B., Mori, J., Miyazawa, M., \& Kano, Y. (2009). Omori-Utsu Law c-Values Associated with Recent Moderate Earthquakes in Japan. Bulletin of the Seismological Society of America, 99(2A), 884-891. https://doi.org/10. $1785 / 0120080211$.

Fedotov, S.A., Gusev, A.A., Chernysheva, G. V., \& Shumilina, L.S. (1985). Seismic focal zone of Kamchatka (geometry, earthquake location and connection to volcanism). Vulkanologiya $i$ seysmologiya, (4), 91-107 (in Russian).

Frolova, T.I., Perchuk, L.L., \& Burikova, I.A. (1989). Magmatism and crustal transformation line with errors in both sets of parameters.

For future work authors plan to continue this work using more geophysical parameters and geological data as well as different technical approaches allowed modeling of geology and geophysical situation in the region and verify it by experimental data. It is possible that further comparison of the results would be fruitful when considering different concepts of deep processes occurred in the Kamchatka region.

in active peripheral regions. Moscow: Nedra, 260 p. (in Russian).

Gontovaya, L. I. \& Nizkous, I. V. (2005). Seismic inhomogeneity of the lithosphere in the suture zone between the Kurile-Kamchatka and Aleutian island arcs: Proc. of the volcanological conference (pp. 175-183). PetropavlovskKamchatsky (in Russian).

Gordienko, V.V. (2001a). Advection-polymorphous process in tectonosphere of transition zone of Pacific ocean type. Geofizicheskiy zhurnal, 23(6), 21-39 (in Russian).

Gordienko, V.V. (2001 b). The nature of mantle and crust conductors. Geofizicheskiy zhurnal, 23(1), 29-39 (in Russian).

Gordienko, V.V. (2014). Deep-seated processes and seismicity activity. Geofizicheskiy zhurnal, 36(1), 19-42 (in Russian). https://doi.org/ 10.24028/gzh.0203-3100.v36i1.2014.116147.

Gordienko, V.V. (2017). Thermal processes, geodynamics, deposits. 283 p. Retrieved from https://docs.wixstatic.com/ugd/6d9890_090e 4a0466b94934b7d7af8c751a70bf.pdf (in Russian).

Gordienko, V.V., Gordienko, I. V., Zavgorodnyaya, O.V., Kovachikova, S., Logvinov, I.M., \& 
Tarasov, V.N. (2011). Ukrainian Carpathians (geophysics, deep-seated processes). Kiev: Logos, 128 p. (in Russian).

Goryachev, A.E. (1966). Kurile-Kamchatka zone: Major patterns of tectonic evolution. Moscow: Nauka, 235 p. (in Russian).

Kadik, A. A., Lukanin, O.A., \& Portnyagin, A. L . (1990). Magma formation with the ascending movement of the mantle substance: the temperature regime and composition of the melts formed during the adiabatic decompression of the ultrabasites of the mantle. Geokhimiya, (9), 1263-1276 (in Russian).

Kissling, E., Ellsworth, W.L., Ederhart-Pillips, D., \& Kradolfer, U. (1994). Initial reference models in local earthquake tomography. Journal of Geophysical Research, Solid Earth, 99(B10), 19635-19646. https://doi.org/10.1029/93JB03 138.

Marakhanov, V. I. \& Potapyev, S. V. (1981). Structural classification of the Kamchatka tectonic region. Moscow: Nauka, 88 p. (in Russian).

Moroz, Yu.F. (1991). Electrical conductivity of the Earth's crust and upper mantle in Kamchatka. Moscow: Nauka, 182 p. (in Russian).

Moroz, Yu.F. (2009). Electrical conductivity of deep-seated strata in Kamchatka's volcanic zones. In: Electromagnetic studies of the Earth. Moscow: Edition of the Institute of Physics of the Earth of the Russian Academy of Sciences, 157 p. (in Russian).

Nizkous, I. V., Kissling, E., Sanina, I.A., \& Gontovaya, L.I., (2006). Velocity characteristics of the lithosphere in Kamchatka's ocean-tocontinent transition zone based on the data of seismic tomography. Fizika Zemli, (4), 18-29 (in Russian).
Rass, I. T., \& Frih-Har, D. I. (1987). About finding of carbonatite in the Upper Cretaceous ultra basic vulcanites of Kamchatka. Doklady AN SSSR, 294(1), 182-186 (in Russian).

Seliverstov, V.A., \& Tsykunov, A. G. (1974). Meymacites of the Northern part of Valaginsky mountain range. Doklady ANSSSR, 217(2), 424427 (in Russian).

Sergeyev, K. F. (Ed.). (1997). Geodynamics of the tectonosphere in the suture zone of the Pacific Ocean and Eurasia, Vol. IV. Structure and material composition of the sedimentary veneer in the northwestern part of the Pacific Ocean. Yuzhno-Sakhalinsk: Edition of the Institute of Marine Geology and Geophysics of the Far Eastern Branch of the Russian Academy of Sciences, 178 p. (in Russian).

Sergeyev, K. F., Gordienko, V. V., \& Krasny, M. L. (Eds.). (1992). Tectonosphere of the Asian Pacific Rim. Vladivostok: Edition of the Far Eastern Branch of the Russian Academy of Sciences, 238 p. (in Russian).

Smirnov, Ya.B., Sugrobov, V.M., \& Yanovskiy, F.A. (1991). Earth heat flow of Kamchatka. Vulkanologiya i seysmologiya, (2), 41-65 (in Russian).

Sobolev, S., Zeyen, H., Stoll, G., Werling, F., Altherr, R., \& Fuchs, K. (1996). Upper mantle temperatures from teleseismic tomography of French Massif Central. Earth and Planetary Science Letters, 139(1-2), 147-163. https://doi. org/10.1016/0012-821X(95)00238-8.

Volynets, O.N., Melekescev, I.V., Ponomareva, V.V., Jagodzinsky, J. M. (1999). Harchinski and Zarechnyi volcanoes - unique centers of late Pleistocene magnesium basalts in Kamchatka: material composition of volcanic rocks. $\mathrm{Vul}$ kanologiya i seysmologiya, (1), 31-45 (in Russian). 


\title{
Deep processes, velocity, heat and density models of the East Kamchatka upper mantle
}

\author{
V. V. Gordienko, L. I. Gontovaya, I. V. Nizkous, 2020
}

For the velocity structure of the lithosphere of East Kamchatka, a tomographic model of high spatial resolution was constructed. Model demonstrates clear relation of velocity values in mantle with subsurface structure. The change in velocity of $P$ waves relative to the average $1 \mathrm{D}$ model reaches $\pm 0.6 \mathrm{~km} / \mathrm{s}$. Asthenosphere, in other words the interval where velocities is lower then in solidus point, can be seen as well. Seismological model may be used to control model of deep processes in the given region. The circuit of the alpine and recent deep processes in the crust and the upper mantle of the East Kamchatka and Cronotsky gulf is considered with use of ideas of a advection-polymorphic hypothesis. Consequences of the processes are coordinated with velocity model of the mantle and composition of magmatic rocks. The data on crustal xenoliths and the composition of igneous rocks of different ages and with different depths of centers of partial melting of mantle rocks were used. The depths of the conductors in the upper mantle are consistent with the deep asthenosphere. But the $S$ values for 1D and 2D models are too large. When using a three-dimensional model in the southern part of Kamchatka, the $S$ value of the electrical conductivity objects in the mantle is reduced. Thus, coordination with the thermal model seems possible. The results of construction of density models of tectonosphere along three cross-sections on the East Kamchatka and adjacent aquatorium are considered. For the model of the upper mantle a thermal model corresponding to the structure of a deep process according to the advection-polymorphous hypothesis is used. The mantle gravitational anomaly reaches a large value - more than 200 mGal. Possibility of explanation of the observed gravitational field without the selection of model parameters is shown.

Key words: Kamchatka, advection-polymorphic hypothesis, velocity, thermal, density and geoelectric models of the upper mantle. 